\title{
Leaf anatomy and morphometry in three eucalypt clones treated with glyphosate
}

\author{
Tuffi Santos, LD. ${ }^{\text {a }}$,Sant'Anna-Santos, BF. ${ }^{\mathrm{c} *}$, Meira, RMSA. ${ }^{\mathrm{c}}$, \\ Ferreira, FA. ${ }^{\mathrm{b}}$, Tiburcio, RAS. ${ }^{\mathrm{b}}$ and Machado, AFL. ${ }^{\mathrm{b}}$ \\ anstituto de Ciências Agrárias, Universidade Federal de Minas Gerais - UFMG, \\ CEP 39400-505, Montes Claros, MG, Brazil \\ bDepartamento de Produção Vegetal, Universidade Federal de Viçosa - UFV, \\ CEP 36570-000, Viçosa, MG, Brazil \\ 'Departamento de Biologia Vegetal, Universidade Federal de Viçosa - UFV, \\ Av. P. H. Rolfs, s/n, Campus Universitário, CEP 36570-000, Viçosa, MG, Brazil \\ *e-mail: brunoufv@yahoo.com.br \\ Received March 9, 2007 - Accepted June 15, 2007 - Distributed February 28, 2009
}

(With 2 figures)

\begin{abstract}
This work aimed to evaluate the effects of simulated drift of glyphosate on the morphoanatomy of three eucalypt clones and to correlate the intoxication symptoms on a microscopic scale with those observed in this visual analysis. The effects of glyphosate drift were proportional to the five doses tested, with Eucalyptus urophylla being more tolerant to the herbicide than E. grandis and urograndis hybrid. The symptoms of intoxication which were similar for the different clones at 7 and 15 days after application were characterized by leaf wilting, chlorosis and curling and, at the highest rates, by necrosis, leaf senescence and death. Anatomically glyphosate doses higher than 86.4 g.ha ${ }^{-1}$ caused cellular plasmolysis, hypertrophy and hyperplasia, formation of the cicatrization tissue and dead cells on the adaxial epidermis. The spongy parenchyma had a decrease, and the palisade parenchyma and leaf blade thickness had an increase. The increased thickness in leaf blade and palisade parenchyma may be related to the plant response to glyphosate action, as a form of recovering the photosynthetically active area reduced by necroses and leaf senescence caused by the herbicide.
\end{abstract}

Keywords: Eucalyptus spp., herbicide, simulated drift, leaf anatomy, phytotoxicity.

\section{Anatomia e morfometria foliar em clones de eucalipto tratados com glyphosate}

\section{Resumo}

Este trabalho teve como objetivo avaliar os efeitos da deriva simulada de glyphosate na morfoanatomia de três clones de eucalipto e correlacionar os sintomas de intoxicação em escala microscópica com aqueles observados à vista desarmada. Os efeitos da deriva do glyphosate foram proporcionais às doses testadas, sendo Eucalyptus urophylla mais tolerante ao herbicida que E. grandis e o híbrido urograndis. Os sintomas de intoxicação foram semelhantes para os diferentes clones testados, tanto aos 7 quanto aos 15 dias após a aplicação, sendo caracterizados, morfologicamente, por murcha, clorose e enrolamento foliar e, no caso das maiores doses, por necrose, senescência foliar e morte das plantas de eucalipto. Anatomicamente, doses de glyphosate superiores a 86,4 g.ha ${ }^{-1}$ provocaram plasmólise, hipertrofia e hiperplasia celular, formação de tecido de cicatrização e morte das células da face adaxial da epiderme. Observou-se diminuição na espessura do parênquima lacunoso e aumento na espessura do parênquima paliçádico e da lâmina foliar. $\mathrm{O}$ aumento na espessura da folha e do parênquima paliçádico podem estar relacionados à resposta das plantas ao glyphosate, como forma de compensar a área fotossinteticamente reduzida pelas necroses e senescência causadas pelo herbicida.

Palavras-chave: Eucalyptus spp., herbicida, deriva simulada, anatomia foliar, fitotoxidez.

\section{Introduction}

Eucalyptus is the most cultivated forest genus in the world, with over 17.8 million hectares planted area, with Brazil ranking third in total planted area. Investment in eucalypt planting and expansion has met the raw mate- rial demand for production of paper and cellulose, vegetal charcoal, saw wood, essential oils, fence posts, and construction and furniture wood. This sector has been recently found to have a great potential for carbon fixation 
and decrease of $\mathrm{CO}_{2}$ concentrations in the atmosphere, generating the interest of the private sector to sequester carbon (Alfenas et al., 2004). The importance of the forest sector, and eucalypt culture, in particular, is partly due to investments on selecting the most productive genotypes and the ones most adapted to each region and to the adoption of more adequate management practices. Such practices allow expressive eucalypt yield gains, which more than tripled in four decades, increasing from $12 \mathrm{~m}^{3} \cdot \mathrm{ha}^{-1} /$ year in 1960 to $40 \mathrm{~m}^{3} \cdot \mathrm{ha}^{-1} /$ year (Barros and Comerford, 2002). Increased yield, reduced production costs and the short time needed to obtain wood, compared to temperate climate forests, confer this sector high competitiveness in the world market.

Weed management is one of most important farming practices especially during the first two years after planting. Weed management becomes one of the major silvicultural problems of eucalypt forestry especially during the rain periods. Management is basically accomplished by chemical and mechanical control methods, alone or in combination (Toledo et al., 2003), with method choice depending on factors such as terrain topography and characteristics of the weed species present. Glyphosate is applied during weed post emergence, favoring operations in minimally cultivated areas (Toledo et al., 2003); in addition, it exerts an effective control over a large number of perennial and annual mono and dicotyledonous weed species, while being completely inactivated when in contact with soil (Malik et al., 1989; Rodrigues and Almeida, 2005).

In areas where chemical control is adopted, the contact of the herbicide molecule with non-target organisms characterizes drift. For example when non-selective products are applied, such as glyphosate based herbicides, the crop itself can suffer from the effects of the herbicide. The extent of crop damage caused by herbicide drift is directly related to the doses recommended for weed control. According to Rodrigues and Almeida (2005), there is a wide variation in the glyphosate doses recommended for eucalypts, with doses ranging from 360 to $2160 \mathrm{~g}$ of e.a. per ha to control annual and perennial species.

The extent of herbicide drift is approached by examining the effects of the herbicide molecule on the yield and morphology of non-target crops. These works involve the concept of the effect of "simulated drift" of the different herbicide formulations on different crops (Bailey and Kapusta, 1993), with a great variation being found in the sub-doses used to define the treatments. Leaf parameters such as leaf lesions, growth, changes caused in foliar micromorphology and anatomic and ultrastructural aspects can be used to qualify and quantify the influence of toxic substances on the plants (Fornasiero, 2001; Silva et al., 2005; Sant'Anna-Santos et al., 2006; Tuffi Santos et al., 2007).

In reforestation areas, glyphosate intoxication of the aerial part of the eucalypt plants has been observed mainly in seedlings and sprouts. In practice, little is known on the behavior of the different genotypes cultivated when exposed to glyphosate drift and on the direct and indirect effects this herbicide molecule has on eucalypts.

Thus, this work aimed to characterize the effects of simulated drift on the leaf anatomy and morphology of three eucalypt genoptypes consisting of clones of two species E. grandis W.Hill ex. Maiden and E. urophylla S.T.Blake, and one hybrid between E. urophylla S.T.Blake X E. grandis W.Hill ex. Maiden. Additionally this work aims to correlate the visual symptoms of intoxication observed with the naked eye with those observed on a microscopic scale.

\section{Material and Methods}

The experiment was carried out in an unprotected environment in an area owned by the Department of Plant Biology of the Universidade Federal de Viçosa, from April 12 to June 15 of $2004\left(23.7 / 14.6{ }^{\circ} \mathrm{C}\right.$ average day/ night temperatures, relative humidity $87.3 \%$ ).

Clonal material of the following genotypes was used: 15 - hybrid of Eucalyptus urophylla S.T. Blake $\mathrm{X}$ E. grandis W. Hill ex. Maiden (urograndis hybrid), 72 - E. urophylla S.T. Blake, both provided by Celulose Nipo-Brasileira SA (CENIBRA), and a clone of E. grandis W. Hill ex. Maiden supplied by the Instituto Estadual de Florestas (IEF). Three month old seedlings, $30 \mathrm{~cm}$ high were planted in pots with $10 \mathrm{~L}$ of clayey soil fertilized with $216.6 \mathrm{~g}$ of N-P-K (6-30-6) and $12 \mathrm{~g}$ of lime in the ratio $\mathrm{Ca}: \mathrm{Mg}=4: 1$ equivalent, with $6 \mathrm{~g} /$ pot of N-P-K (20-5-20) applied 15 days after planting (DAP) of the seedlings, and three applications of $4 \mathrm{~g} / \mathrm{pot}$ of $\left(\mathrm{NH}_{4}\right)_{2} \mathrm{SO}_{4}$ at 40, 60 and 80 DAP. A factorial scheme (three clones and five treatments) was used, arranged in a randomized block design, with four repetitions, each pot constituting an experimental plot. The five treatments consisted of the following doses of Isopropylamine salt of N-phosphonometly glycine (glyphosate: Commercial brand name Roundup SC, Monsanto of Brazil Ltd): 0, $43.2,86.4,172.8$ and $345.6 \mathrm{~g}$ e.a. ha $^{-1}$ corresponding to $0,3,6,12$ and $24 \%$ of the glyphosate dose of $1.440 \mathrm{~g}$ e.a. ha ${ }^{-1}$. The glyphosate was applied 23 days after transplanting when the seedlings were $35 \mathrm{~cm}$ high using a backpack sprayer equipped with a hand-held boom consisting of two flat fan nozzles TT 110.02 , spaced $0.5 \mathrm{~m}$ apart, $250 \mathrm{kPa}$ of pressure, and volume of $200 \mathrm{~L}^{\mathrm{h}} \mathrm{ha}^{-1}$ was used. The herbicide was applied on the plants so as not to reach the superior third. Application was performed in a covered area where the plants remained for 24 hours after application. Weather conditions at the time of application were relative humidity of $85 \%$, air temperature of $21{ }^{\circ} \mathrm{C}$ and no wind.

After herbicide application, morphological changes in the aerial part of the plants were daily evaluated. For anatomic characterization of the effects caused by glyphosate, leaves from the third node were collected from the first basal branch of the eucalypt plants at 7 and 15 days after application (DAA). The samples were fixed in $\mathrm{FAA}_{50}$ (1 formalin/1 acetic acid/18 ethanol 50\%) 
and stored in ethanol 70\% (Johansen, 1940). Samples of the central portion of the leaves were dehydrated in an ethylic/butylic series and embedded in histological paraffin (Johansen, 1940). Transversal cuts, $12 \mu \mathrm{m}$ thick, were obtained by using an automatic rotative microtome (model RM2155, Leica Microsystems Inc., Deerfield, USA). The cuts were stained with basic fuchsine and astra blue (Gerlach, 1984) and the slides mounted with synthetic Canada balsam. Analyses and photographic documentation were performed using a light microscope (model AX70TRF, Olympus Optical, Tokyo, Japan) with U-Photo system and digital camera (model 3.2.0 Spot Insight color, Diagnostic Instruments, Inc., USA).

Thickness of the leaf blade, palisade parenchyma (Pp), spongy parenchyma (Sp) and adaxial (Ade) and abaxial (Abe) epidermis were measured in the transversal cuts, for the three clones studied. Thickness data were obtained by means of the software "Image-Pro Plus", with a total of 27 observations/repetition for each structure evaluated.

The data obtained were submitted to analysis of variance by the F test, and the averages compared by the Tukey test at $5 \%$ probability.

\section{Results}

\subsection{Morphological characterization}

Intoxication was proportional to the doses tested, with the most intense being verified in the plants treated with the highest glyphosate doses. The first intoxication was observed at 4 DAA and characterized at 7 DAA by wilting, chlorosis and curling of the apical leaves of the plants sprayed with glyphosate doses at concentrations above $86.4 \mathrm{~g} \cdot \mathrm{ha}^{-1}$. Also, necrosis and death of the terminal twigs and branches were observed at greater intensity in plants of $E$. grandis and urograndis hybrid treated with 172.8 and 345.6 g.ha ${ }^{-1}$ of glyphosate. Necroses occurred mainly on the leaf margins and close to the leaf midrib. Plants of E. grandis sprayed with glyphosate dose of 345.6 g.ha ${ }^{-1}$ presented severe intoxication symptoms at 15 DAA. At the same time, slight chlorosis and apical wilting were visible in the three clones treated with 43.2 g.ha ${ }^{-1}$ of glyphosate, being more evident in E. grandis. However, these symptoms disappeared at 45 DAA, indicating a total recovery of the plants.

From 30 DAA, new sprouts were observed in plants of E. urophylla and urograndis hybrid treated

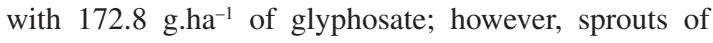
urograndis hybrid showed more intense symptoms than E. urophylla. New sprouts were not observed in E. grandis and in plants of the three clones treated with the highest glyphosate dose (345.6 g.ha ${ }^{-1}$ ).

E. grandis was most susceptible to glyphosate with $75 \%$ seedling death at 45 DAA in plants treated with 345.6 g.ha ${ }^{-1}$ of glyphosate, while E. urophylla and the hybrid E. urophylla x E. grandis had 15 and $0 \%$ dead plants respectively.

\subsection{Anatomical characterization}

The three Eucalyptus clones studied presented dorsiventral and amphistomatic leaves, with the adaxial epidermis showing a reduced number of stomata which where generally restricted to the area around the midrib. Leaves were glabrous with uniseriated epidermis covering the mesophyll formed by prominent spongy parenchyma and a palisade parenchyma layer (Figure 1a).

In all the clones, the anatomical analysis of the injuries caused by glyphosate showed similar symptoms both at 7 and 15 DAA. Anatomic injuries were observed in the leaves of the plants exposed to glyphosate doses of $86.4 ; 172.8$ and $345.6 \mathrm{~g} \mathrm{ha}^{-1}$ in the three clones evaluated. These injuries included the occurrence of plasmolyzed epidermal cells on the adaxial face of the leaf, as well as hypertrophy of the chlorophyll parenchyma cells leading to the collapse of this tissue (Figures $1 \mathrm{~b}$ and 1c) morphologically seen as necrotic areas, and the decrease of the intercellular spaces in the spongy parenchyma (Figure 1c). In areas where either plasmolyzed cells were found, cells with hypertrophy or close to the necrotic areas there were compounds that stained an intense red colour with fuchsine stain (Figure 1d).

As a response to injury, hyperplasia of the mesophyll cells was induced, leading to the formation of a cicatrization tissue (Figures 1e and 1f) constituted by volumous cells of thickened cellular walls (Figures 1f and 1g), isolating the necrotic areas of the non-affected tissues (Figures 1e).

Secretory cavities are dispersed in the mesophyll under the epidermis (Figure 2a). The midrib has bicollateral vascular bundles (Figure 2a), with the presence of calcium oxalate crystals being common (druses and monocrystals). The midrib shows cellular plasmolysis and consequent formation of large intercellular spaces, as well as hypertrophy of the parenchyma cells and intense coloration caused by fuchsine in the affected areas (Figures 2b and 2c). Plasmolysis of almost all the tissue was verified in the necrotic midrib, with only the xylem elements remaining apparently intact with well-defined cell shape (Figure 2d).

\subsection{Micromorphometric analysis}

At 7 DAA, a sub-dose and clone evaluated interaction was observed for thickness of the spongy parenchyma (Sp) $(\mathrm{p}<0.01)$, with no effect of the isolated factors on the variables studied being observed $(p>0.05)$. The sub-dose $x$ clone $(p<0.01)$ interaction was observed at 15 DAA for thickness of the leaf blade and palisade parenchyma (Pp). An isolated sub-dose and clone effect was observed $(p<0.01)$ on thickness of Sp but not ( $p>0.05$ ) for leaf blade, Pp, adaxial (Ade) and abaxial (Abe) epidermis.

Values at 7 DAA and their respective average tests for the three clones are shown in Table 1. The urograndis hybrid and E. urophylla presented a higher Sp thickness than E. grandis for 0, 43.2 and 345.6 g.ha ${ }^{-1}$ of glyphosate (Table 1). In E. urophylla, at 7 DAA, there was an in- 

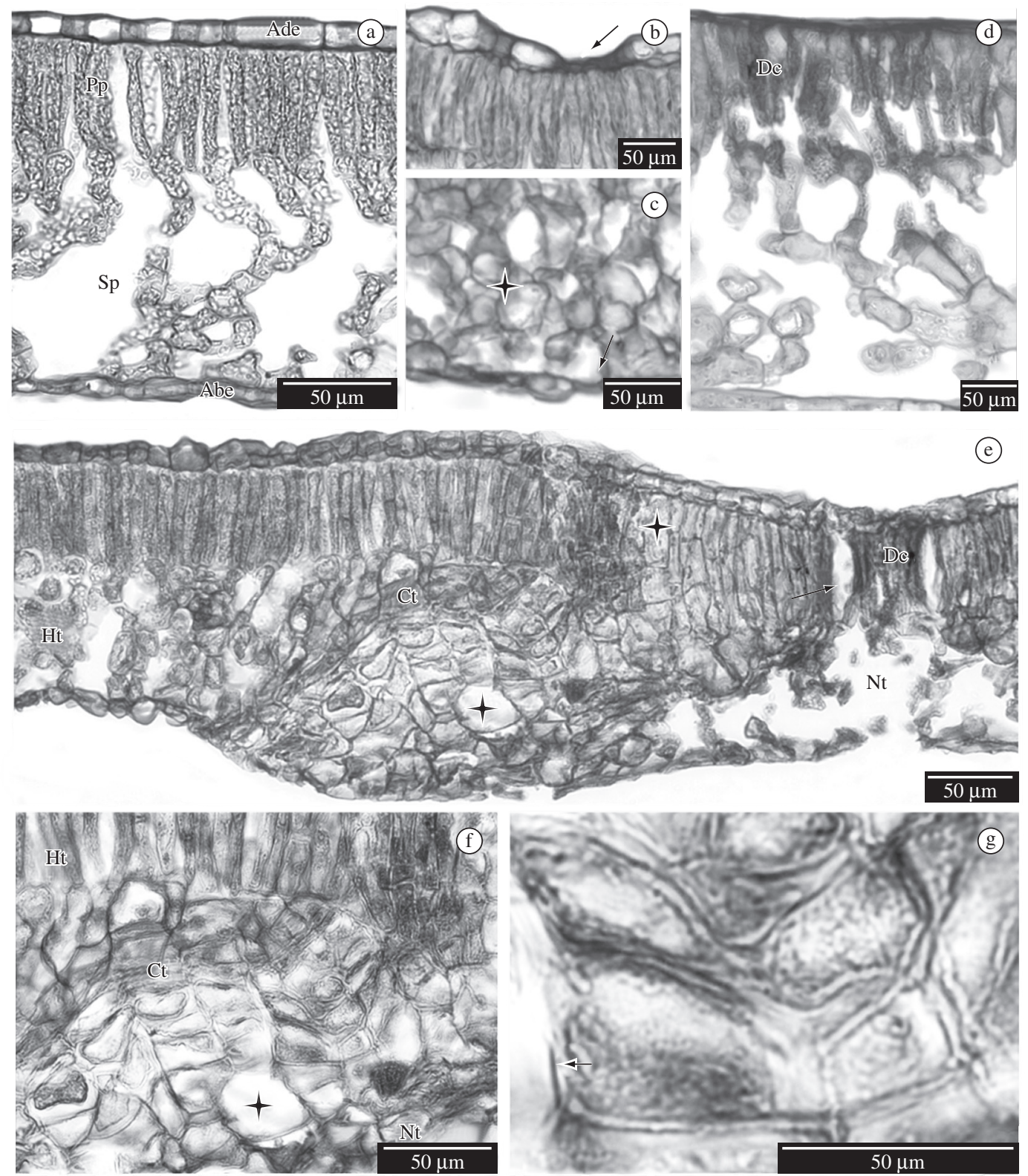

Figure 1. Leaf blade structure of Eucalyptus sp. (light micrographs of cross sections). a) Control treatment. b-g) Glyphosate. a) Leaf mid-region. b) Beginning of necrosis in the adaxial epidermis; accumulation of dark compounds (arrow). c) Beginning of necrosis in the abaxial epidermis (arrow); reduction of intercellular spaces and hypertrophy in spongy parenchyma (cross). d) Palisade parenchyma cells with dark contents. e) Formation of a cicatrization tissue in the region adjacent to necrosis, hypertrophy (cross) in the mesophyll cells and dark contents in the palisade parenchyma. f) Detail of transition area between the necrotic and healthy tissues showing hypertrophy (cross) and hyperplasia of cicatrization cells. g) Detail of figure f: arrow indicates large cells with thick walls in cicatrization tissue. Abbreviations: Ade: adaxial epidermis; Abe: abaxial epidermis; Pp: palisade parenchyma; Sp: spongy parenchyma; Dc: dark contents; Ct: cicatrization tissue; Ht: healthy tissue; Nt: necrotic tissue.

crease in Pp thickness in plants exposed to doses higher than 86.4 g.ha ${ }^{-1}$ of glyphosate (Table 1), the same being verified for the three clones at 15 DAA (Table 3). On the other hand, in urograndis hybrid and E. grandis a tendency to increased $\mathrm{Sp}$ thickness was observed proportionally to the increase of the doses at 7 DAA (Table 1).
However, E. grandis plants treated with glyphosate dose of 345.6 g.ha ${ }^{-1}$ presented the smallest Sp thickness at 7 DAA (Table 1). Such a fact may be attributed to the foliar tissue collapse caused by glyphosate in this species, given the greater sensitivity of this clone to the herbicide. 

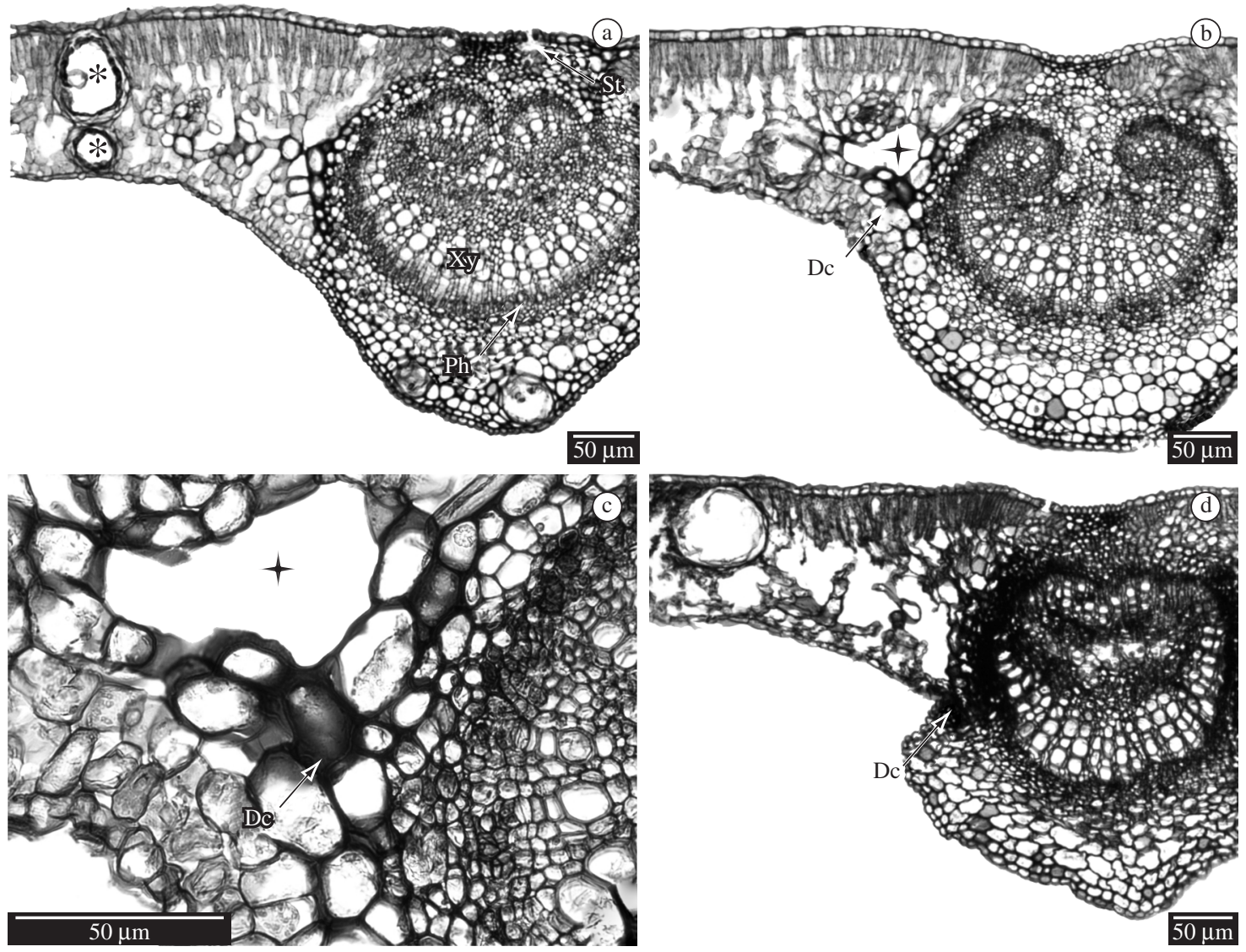

Figure 2. Leaf blade structure of Eucalyptus sp. (light micrographs of cross sections). a) Control treatment. b-d) Glyphosate. a) Midrib: secretory cavities in the mesophyll (*). b) Accumulation of dark compounds and large intercellular spaces (cross) near midrib. c) Detail of accumulation of dark compounds and large intercellular spaces (cross). d) Necrosis in midrib. Abbreviations: St: stomata; Ph: phloem; Xy: xylem Dc: dark contents.

Table 1. Mean thickness values of the palisade and spongy parenchymas of eucalypt plants submitted to glyphosate doses of $0 ; 43.2 ; 86.4 ; 172.8$ and 345.6 g.ha ${ }^{-1}$ at 7 DAA.

\begin{tabular}{|c|c|c|c|c|c|}
\hline \multirow[t]{3}{*}{ Clone } & \multicolumn{5}{|c|}{ Doses (g.ha ${ }^{-1}$ of glyphosate) } \\
\hline & $\mathbf{0}$ & 43.2 & 86.4 & 172.8 & 345.6 \\
\hline & \multicolumn{5}{|c|}{ Palisade parenchyma $(\mu \mathbf{m})$} \\
\hline Hybrid urograndis & $66.10 \mathrm{Aa}$ & $62.56 \mathrm{Aa}$ & $69.72 \mathrm{Aa}$ & $64.42 \mathrm{Aa}$ & $63.77 \mathrm{Aa}$ \\
\hline E. urophylla & $56.81 \mathrm{BCa}$ & $54.24 \mathrm{Ca}$ & $66.06 \mathrm{ABa}$ & $71.29 \mathrm{Aa}$ & $64.10 \mathrm{ABa}$ \\
\hline \multirow[t]{2}{*}{ E. grandis } & $67.91 \mathrm{Aa}$ & $59.59 \mathrm{Aa}$ & $68.45 \mathrm{Aa}$ & $67.89 \mathrm{Aa}$ & $65.94 \mathrm{Aa}$ \\
\hline & \multicolumn{5}{|c|}{ Spongy parenchyma $(\mu \mathrm{m})$} \\
\hline Hybrid urograndis & $88.36 \mathrm{ABa}$ & $94.97 \mathrm{Aa}$ & $85.29 \mathrm{Bb}$ & $99.74 \mathrm{Aa}$ & $96.51 \mathrm{Aa}$ \\
\hline E. urophylla & $92.15 \mathrm{Aa}$ & $94.68 \mathrm{Aa}$ & $101.56 \mathrm{Aa}$ & $92.00 \mathrm{Aa}$ & $94.76 \mathrm{Aa}$ \\
\hline E. grandis & $83.59 \mathrm{ABb}$ & $85.38 \mathrm{ABb}$ & $89.93 \mathrm{Ab}$ & $92.71 \mathrm{Aa}$ & $75.69 \mathrm{Bb}$ \\
\hline
\end{tabular}

Means followed by small letters in the column and capital letters in the line do not differ by the Tukey test at $5 \%$ probability.

At 15 DAA, E. urophylla presented the largest $\mathrm{Sp}$ thickness, followed by urograndis hybrid and E. grandis, evidencing the decreased thickness of this tissue in glyphosate-treated plants, regardless of the clone ana- lyzed (Table 2). The increase in Pp thickness of all clones exposed to glyphosate doses above $86.4 \mathrm{~g} \cdot \mathrm{ha}^{-1}$ led to an increase in leaf blade thickness only on urograndis hybrid (Table 3 ). 
Table 2. Mean thickness values of the spongy parenchyma of eucalypt plants submitted to doses of $0 ; 43.2 ; 86.4 ; 172.8$ and 345.6 g.ha ${ }^{-1}$ of glyphosate, at 15 DAA.

\begin{tabular}{lcccccc}
\hline \multirow{2}{*}{ Clone } & \multicolumn{7}{c}{ Doses $\left(\right.$ g.ha ${ }^{-1}$ of glyphosate) } \\
\cline { 2 - 7 } & $\mathbf{0}$ & $\mathbf{4 3 . 2}$ & $\mathbf{8 6 . 4}$ & $\mathbf{1 7 2 . 8}$ & $\mathbf{3 4 5 . 6}$ & Mean \\
\cline { 2 - 7 } & 111.06 & 100.69 & 100.71 & 103.19 & 104.65 & $104.06 \mathrm{~B}$ \\
\hline Hybrid urograndis & 112.98 & 113.21 & 107.26 & 108.98 & 106.89 & $109.86 \mathrm{~A}$ \\
E. urophylla & 93.34 & 89.01 & 87.64 & 96.26 & 86.17 & $90.48 \mathrm{C}$ \\
E. grandis & $105.79 \mathrm{~A}$ & $100.97 \mathrm{AB}$ & $98.53 \mathrm{~B}$ & $102.81 \mathrm{AB}$ & $99.23 \mathrm{~B}$ & \\
Mean & \multicolumn{7}{c}{ Spongy parenchyma $(\mu \mathrm{m})$} \\
\hline
\end{tabular}

Means followed by the same letter do not differ by the Tukey test at $5 \%$ of probability.

Table 3. Mean thickness values of the leaf blade and palisade parenchyma $(\mu \mathrm{m})$ of eucalypt plants submitted to glyphosate doses of $0 ; 43.2 ; 86.4 ; 172.8$ and $345.6{\mathrm{~g} . \mathrm{ha}^{-1}}^{-1}$ at 15 DAA.

\begin{tabular}{lccccc}
\hline \multicolumn{1}{c}{ Clone } & \multicolumn{5}{c}{ Doses (g.ha ${ }^{-1}$ of glyphosate) } \\
\cline { 2 - 6 } & \multicolumn{7}{c}{$\mathbf{0}$} & $\mathbf{4 3 . 2}$ & $\mathbf{8 6 . 4}$ & $\mathbf{1 7 2 . 8}$ & $\mathbf{3 4 5 . 6}$ \\
\cline { 2 - 6 } & \multicolumn{5}{c}{ Leaf blade $(\mu \mathrm{m})$} \\
\hline Hybrid urograndis & $185.50 \mathrm{Ba}$ & $184.46 \mathrm{Ba}$ & $210.57 \mathrm{Aa}$ & $216.76 \mathrm{Aa}$ & $200.94 \mathrm{Aa}$ \\
E. urophylla & $202.25 \mathrm{Aa}$ & $200.41 \mathrm{Aa}$ & $201.64 \mathrm{Aa}$ & $200.30 \mathrm{Aab}$ & $199.61 \mathrm{Aa}$ \\
E. grandis & $184.72 \mathrm{Aa}$ & $182.15 \mathrm{Aa}$ & $165.93 \mathrm{Ab}$ & $185.73 \mathrm{Ab}$ & $176.76 \mathrm{Ab}$ \\
\cline { 2 - 6 } & \multicolumn{7}{c}{ Palisade parenchyma $(\mu \mathrm{m})$} \\
Hybrid urograndis & $59.87 \mathrm{Ba}$ & $63.65 \mathrm{Ba}$ & $79.95 \mathrm{Aa}$ & $74.38 \mathrm{Aa}$ & $72.86 \mathrm{Aa}$ \\
E. urophylla & $59.68 \mathrm{Ba}$ & $58.99 \mathrm{Ba}$ & $69.18 \mathrm{Ab}$ & $66.52 \mathrm{Aa}$ & $67.40 \mathrm{Aa}$ \\
E. grandis & $59.50 \mathrm{Ba}$ & $62.82 \mathrm{ABa}$ & $62.04 \mathrm{ABc}$ & $65.88 \mathrm{ABa}$ & $68.30 \mathrm{Aa}$ \\
\hline
\end{tabular}

Means followed by the same small letter in the column and capital letter in the row do not differ by the Tukey test at $5 \%$ of probability.

\section{Discussion}

In this study the development of injuries to the older parts of the eucalypt plants caused by glyphosate drift to the younger parts of the plants were verified, and corroborates literature reports and the fact that glyphosate is a systemic product of high mobility in the plant. According to Bromilow and Chamberlain (2000), glyphosate applied to the leaves is highly mobile in the plant and distributed through the symplastic pathway to the roots and the meristematic regions of the plant, during leaf application. The injuries caused by glyphosate develop from the younger parts towards the older parts as a result of weed control applications when adequate doses are used, and a result of drift when sub-doses of the product come into contact with non-target plants (Tuffi Santos et al., 2005; Tuffi Santos et al., 2007; Magalhães et al., 2001). The herbicide's high mobility would explain the occurrence of the necroses concentrated on the borders and on the region close to the midrib of the leaves.

Wilting, chlorosis and necrosis symptoms observed in this study were also reported by Tuffi Santos et al. (2005) and Tuffi Santos et al. (2007), in urograndis hybrid plants sprayed with 172.8 and 345.6 g.ha ${ }^{-1}$ of glyphosate. Chloroplast degeneration (Campbell et al., 1976) and/or inhibition of chlorophyll formation (Cole et al., 1983) in plants treated with this herbicide have probably caused the observed chloroses.

The appearance of sprouts with intoxication symptoms in glyphosate-treated plants aiming at stump regrowth control was described by Dantas et al. (2001). Tuffi Santos et al. (2005) described the emission of normal and abnormal sprouts with intoxication symptoms in eucalyptus plants submitted to simulated drift at glyphosate doses of 172.8 and 345.6 g.ha ${ }^{-1}$. Magalhães et al. (2001), working with glyphosate drift simulation in maize and sorghum cultures, observed a drop in yield and necroses in the aerial part of the treated plants with doses over $8 \%$ of the dose of 1440 g.hat ${ }^{-1}$ and that the sub-dose of $12 \%$ caused $53 \%$ of intoxication in the plants.

The anatomic structures observed in the species E. grandis and E. urophylla as well as in the hybrid urograndis are similar, and agree with the description of the genus Eucalyptus (Metcalfe and Chalk, 1979; Metcalfe, 1987). The cellular contents stained intensely dark red by fuchsine in plants treated with the highest doses of glyphosate are probably associated with the accumulation of phenolic compounds in similarity to responses in other plants exposed to herbicides and pollutants (Silva et al., 2005; Tuffi Santos et al., 2005; Sant'Anna-Santos et al., 2006), with the phenolic nature of these compounds 
was confirmed through specific histochemical reactions by Soukupová et al. (2001) in species of the genus Picea. However, histochemical tests must be carried out to confirm the nature of these contents in eucalypt leaves exposed to glyphosate drift. The presence of phenolic compounds is common in the genus Eucalyptus (Metcalfe, 1987) and the accumulation of these substances is a defense mechanism activated by biotic and abiotic factors which induce stress (Vaughn and Duke, 1994).

Glyphosate killed epidermal cells of all three clones examined in similarity to reports by Tuffi Santos et al. (2005) on urograndis hybrid plants exposed to glyphosate drift. Dead epidermal cells may facilitate a route for pathogen entry into eucalypt plants exposed to glyphosate drift (Tuffi Santos et al., 2005; Tuffi Santos et al., 2007). In addition, Rizzardi et al. (2003) report that subdoses of glyphosate may facilitate the attack of pathogens due to a reduction in accumulation of phytoalexins and lignin (Lévesque and Rahe, 1992) which are both considered physical-physiological barriers of the plant. Thus, the predisposition of the eucalypt plants to a greater susceptibility to diseases in addition to the anatomical damage caused by glyphosate drift in this crop is a fact that must be further investigated for a better understanding of plant, pathogen and glyphosate interrelations.

The anatomical and morphological responses in eucalypt plants treated with glyphosate, under simulated drift, are evident and, in general, associated with plant protection and rehabilitation. The differentiation of a cicatrization tissue in eucalypt clones submitted to glyphosate drift acts as a barrier preventing necrosis to develop into other leaf regions and results from the ability of these plants to forming new tissues based on the proliferating capacity of the parenchyma cells (Dickison, 2000). The formation of this barrier in response to stress would prevent necrosis development into other leaf regions as observed in response to other stress such as atmospheric pollutants (Silva et al., 2005; Sant'Anna-Santos et al., 2006). Increase in Pp thickness and proportional area may be the response of the plants to compensate the loss of the photosynthetic area due to foliar senescence and necroses caused by glyphosate action. Thickness variation of the Sp and $\mathrm{Pp}$ and, consequently, of the leaf blade in glyphosate-treated plants may be the result of cellular proliferation and hyperplasia observed in the foliar mesophyll tissues of eucalypt plants exposed to drift. Abu-Irmaileh et al. (1979) reported increased cellulases yield in bean plants treated with glyphosate. The likely increase in the concentrations of these enzymes in the foliar tissues of eucalyptus may loosen the structure of the mesophyll cell walls, leading to their expansion.

The morphological data show a differential herbicide tolerance among the three clones studied, with $E$. grandis being more susceptible to glyphosate drift. However, the anatomical structure and histological changes found in the leaves of plants exposed to glyphosate are similar for the three clones, with no marked differences being found to explain the tolerance difference. Some literature works show that plant tolerance to glyphosate is due to a differential penetration or translocation (Sandberg et al., 1980; D'Anieri et al., 1990; Satichivi et al., 2000; Monquero et al., 2004). The herbicide absorption rates and, consequently, their efficacy, are directly related to the types of structures found in the leaf and to cuticle permeability (Baker, 1982), which, in turn, depends on its chemical constitution and polarity. Studies show that the stomata, where the cuticle on the guard cells is thinner and more permeable to polar substances (lower content of epicuticular wax), are a likely route to herbicide penetration (Hess and Falk, 1990; Schreiber, 2005). Such a fact may favor glyphosate penetration in plants where the presence of stomata is significant, mainly on the adaxial face of the foliar epidermis, where the contact with the herbicide applied in most plants is largest. The three eucalyptus clones studied have stomata in both epidermal faces; however, the reduced number of stomata on the adaxial face and the limiting drift contact with the abaxial face of the foliar epidermis make the stomata an unlikely route of glyphosate absorption.

Further studies on the characterization and constitution of the foliar cuticle as well as on glyphosate penetration and translocation are needed to elucidate the differential tolerance shown by different eucalyptus genotypes to glyphosate drift.

The effects of glyphosate drift are proportional to the doses applied, with E. urophylla being more tolerant than urograndis hybrid and $E$. grandis, respectively.

Glyphosate doses of 43.6 and 86.4 g.ha ${ }^{-1}$ caused a slight intoxication in the plants of the three clones, with a total recovery of those treated with 43.6 g.ha ${ }^{-1}$ being observed with time.

Glyphosate altered the thickness and proportion of the leaf blade tissues, with the greatest changes being observed in the palisade parenchyma.

There is a similarity among the clones studied between the morphological and anatomic changes observed in the plants treated with the highest doses of glyphosate. No significant difference was found in the microscopic observations that may explain the difference in tolerance among the studied clones exposed to glyphosate drift.

\section{References}

ABU-IRMAILEH, BF., JORDAN, LS. and KUMAMOTO, J., 1979. Enhancement of $\mathrm{CO}_{2}$ and ethylene producion and cellulase activity by glyphosate in Phaseolus vulgaris. Weed Sci., vol. 27, no. 1, p. 103-106.

ALFENAS, AC., ZAUZA, EAV., MAFIA, RG. and ASSIS, TF., 2004. Clonagem e doenças do eucalipto. Viçosa: UFV.

BAILEY, JA. and KAPUSTA, G., 1993. Soybean (Glycine max) tolerance to simulated drift of nicosulfuron and primisulfuron. Weed Technol., vol. 7, no. 3, p. 740-745.

BAKER, EA., 1982. Chemistry and morphology of plant epicuticular waxes. In: Cutler, DF., Alvin, K.L., Price, C.E. (Ed.). The plant cuticle. London: Academic Press. 
BARROS, NF. and COMERFORD, NB., 2002. Sustentabilidade da produção de florestas plantadas na região tropical. Tópicos em Ciência do Solo, vol. 2, no. 2, p. 487-592.

BROMILOW, RH. and CHAMBERLAIN, K., 2000. The herbicide glyphosate and related molecules: physicochemical and structural factors determining their mobility in phloem. Pest Manag. Sci., vol. 56, no. 4, p. 368-373.

CAMPBELL, WF., EVANS, JO. and REED, FC., 1976. Effect of glyphosate on chloroplast ultrastructure of quack grass mesophyll cell. Weed Sci., vol. 24, no. 1, p. 22-25.

COLE, DJ., CASELEY, JC. and DODGE, AD., 1983. Influence of glyphosate on selected plant process. Weed Res., vol. 23, no. 3, p.173-183.

D'ANIERI, P., ZEDAKER, SM., SEILER, JR. and KREH, RE., 1990. Glyphosate translocation and efficacy relationships in red maple, sweet gum and loblolly pine seedlings. Forestry Science, vol. 36, no. 2, p. 438-447.

DANTAS, FWF., SOUZA, AJ. and CIERO, AD., 2001. Controle da rebrota de eucalipto em área de reflorestamento. In: Anais do Seminário nacional sobre herbicidas e tecnologia de aplicação em florestas. Viçosa: SBS/ SIF, p. 29-44.

DICKISON, WC., 2000. Integrative Plant Anatomy. Massachusetts: Harcourt/Academic Press.

FORNASIERO, RB., 2001. Phytotoxic effects of fluorides. Plant Sci., vol. 161, no. 5, p.979-985.

GERLACH, D. 1984. Botanische mikrotechnik. Stuttgard: Georg Thieme Verlag.

HESS, FD. and FALK, RH., 1990. Herbicide deposition on leaf surfaces. Weed Sci., vol. 38, no. 3, p. 280-288.

JOHANSEN, DA., 1940. Plant microtechique. New York: McGraw-Hill Book.

LÉVESQUE, CA. and RAHE, JE., 1992. Herbicide interaction with fungal root pathogens, with special reference to glyphosate. Ann. Rev. Phytopathol. vol. 30, no. 1, p. 579-602.

MAGALHÃES, PC., SILVA, JB., DURÃES F., KARAM, D. and RIBEIRO, LS., 2001. Efeito de doses reduzidas de glyphosate e paraquat simulando deriva na cultura do milho. Planta Daninha, vol. 19, no. 2, p. 247-253.

MALIK, J., BARRY, G. and KISHORE, G., 1989. The Herbicide Glyphosate. Biofactores, vol. 2, no. 1, p. 17-25.

METCALFE, CF. and CHALK, L., 1979. Anatomy of the dicotyledons. Systematic anatomy of leaf and stem, with a brief history of the subject. 2 ed. Oxford: Clarendon Press.

METCALFE, CF., 1987. Anatomy of the dicotyledons. 1 ed. Oxford: Clarendon Press.

MONQUERO, PA., CHRISTOFFOLETI, PJ., MATAS, JA. and HEREDIA, A., 2004. Caracterização da superfície foliar e das ceras epicuticulares em Commelina benghalensis, Ipomoea grandifolia e Amaranthus hybridus. Planta Daninha, vol. 22, no. 2, p. 203-210.

RIZZARDI, MA., FLECK, NG., AGOSTINETO, D. and BALBINOT, JRAA., 2003. Ação dos herbicidas sobre o mecanismo de defesa das plantas aos patógenos. Ciência Rural, vol. 33, no. 5, p. 957-965.

RODRIGUES, BN. and ALMEIDA, FS., 2005. Guia de herbicidas. 5 ed. Londrina: Grafmarke. 591p.

SANDBERG, CL., MEGGITT, WF. and PENNER, D., 1980. Absorption, translocation and metabolism of ${ }^{14} \mathrm{C}$-glyphosate in several weed species. Weed Res., vol. 20, no. 4, p. 195-200.

SANT'ANNA-SANTOS, BF., SILVA, LC., AZEVEDO, AA., ARAÚJO, JM., ALVES, EF., SILVA, EAM. and AGUIAR, RME., 2006. Effects of simulated acid rain on the foliar micromorphology and anatomy of tree tropical species. Environ. Exp. Bot., vol. 58, no. 1-3, p. 168-158.

SATICHIVI, NM., WAX, LM., STOLLER, EW. and BRISKIN, DP., 2000. Absorption and translocation of glyphosate isopropylamine and trimethysulfonium salts in Abutilon theophrasti and Setaria faberi. Weed Sci., vol. 48, no. 6, p. $675-679$

SCHREIBER, L., 2005. Polar paths of diffusion across plant cuticles: new evidence for an old hypothesis. Ann. Bot., vol. 95, no. 7 , p. $1069-1073$

SILVA, LC., OLIVA, MA., AZEVEDO, AA., ARAÚJO, JM. and AGUIAR, RM., 2005. Micromorphological and anatomical alterations caused by simulated acid rain in restinga plants: Eugenia uniflora and Clusia hilariana. Water, air and soil pollution, vol. 68 , no. 1-4, p. 129-143.

SOUKUPOVÁ, J., ROCK, BN. and ALBRECHTOVÁ, J., 2001. Comparative study of two spruce species in a polluted mountainous region. New Phytologist, vol. 150, no. 1, p. 133-145.

TOLEDO, REB., VICTORIA FILHO, R., ALVES, PLCA., PITELLI, RA. and LOPES, MAF., 2003. Faixas de controle de plantas daninhas e seus reflexos no crescimento de plantas de eucalipto. Scientia Forestalis, vol. 64, no. 1, p. 78-92.

TUFFI SANTOS, LD., FERREIRA, FA., MEIRA, RMSA., BARROS, NF., FERREIRA, LR. and MACHADO, AFL., 2005. Crescimento e morfoanatomia foliar de eucalipto sob efeito de deriva do glyphosate. Planta Daninha, vol. 23, no. 1, p. $133-142$

TUFFI SANTOS, LD., MEIRA, RMSA., FERREIRA, FA., SANT'ANNA-SANTOS, BF. and FERREIRA, LR., 2007. Morphological responses of different eucalypt clones submitted to glyphosate drift. Environ. Exp. Bot., vol. 59, no. 1, p. 11-20.

VAUGHN, K. and DUKE, SO., 1994. Function of polyphenol oxidase in higher plants. Phisiol. Plant., vol. 60, no. 1, p. 106-112 